\title{
The relationship between experiential avoidance and autism spectrum traits with hoarding behaviors with mediating role of saving cognitions
}

\author{
Ashraf Zangooii ${ }^{1}$, Qasem Ahi $^{2}$, Fatemeh Shahabizadeh ${ }^{3}$ \\ 1- Master of Clinical Psychology, Department of Psychology, Birjand Branch, Islamic Azad University, Birjand, \\ Iran. ORCID: 0000-0003-2306-6195 \\ 2- Assistant professor, Department of Psychology, Birjand Branch, Islamic Azad University, Birjand, Iran \\ (Corresponding Author). ORCID: 0000-0002-2772-7053_E-mail: Ahigh1356@yahoo.com \\ 3- Associate professor, Department of Psychology, Birjand Branch, Islamic Azad University, Birjand, Iran. \\ ORCID: 0000-0001-5309-9516
}

Received: $18 / 02 / 2019$

Accepted: 29/04/2019

\begin{abstract}
Introduction: Hoarding disorder is a complex and not well-understood psychological state that affects millions of people worldwide.

Aim: The purpose of this study was to examining the relationship between experimental avoidance and autism spectrum traits and hoarding behaviors with the mediating role of hoarding cognitions.

Method: The present study was descriptive of correlational type and the statistical society of this study was all students of Birjand Azad University in the academic year of 2016-17. The sample consisted of 369 people who were selected by random cluster sampling and completed the Saving Inventory-Revised, hoarding cognitions questionnaire, experiential avoidance questionnaire and autism spectrum quotient.

Results: The findings of the study showed that experiential avoidance has a positive and significant relationship with aspects of hoarding, while the autism spectrum traits have no relationship with the cognitive and behavioral aspects of hoarding. In addition, a finding on mediating role showed that in the proposed model, only the experiential avoidance has a mediator role.
\end{abstract}

Conclusion: The findings of the study supported hoarding cognitive- behavioral models and suggested that experiential avoidance and hoarding cognitions play important roles in the growth and maintenance of the problems associated with hoarding.

Keywords: Hoarding behaviors, Hoarding cognitions, Experiential avoidance, Autism spectrum traits

\footnotetext{
How to cite this article : Zangooii A, Ahi Q, Shahabizadeh F. Examining the relationship of between experiential avoidance and autism spectrum traits with hoarding behaviors with mediating role of saving cognitions. Shenakht Journal of Psychology and Psychiatry. 2019; 6 (3): 15-30 .URL: http://shenakht.muk.ac.ir/article-1-505-fa.pdf
}

Copyright (C) 2018 the Author (s). Published by Kurdistan University of Medical Sciences. This is an open access article distributed under the terms of the Creative Commons Attribution-Non Commercial License 4.0 (CCBY-NC), where it is permissible to download, share, remix, transform, and buildup the work provided it is properly cited. The work cannot be used commercially without permission from the journal. 


\title{
بررسى ارتباط بين اجتناب تجربى و صفات طيف اوتيسم با رفتار هاى احتكارى: نقش ميانجى شناختار هاى احتكارى
}

\author{
اشرف زنكويى'، قاسم آهى'، فاطمه شهابى زاده؟

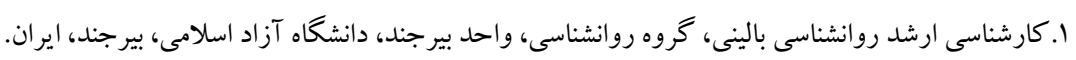

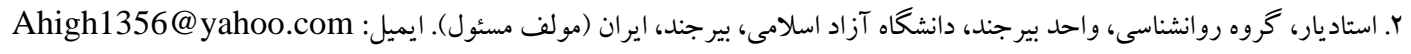

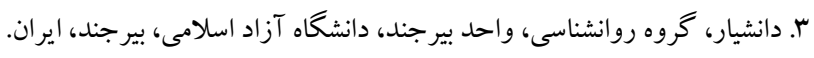

مقدمه: اختلال احتكار يكك وضعيت روانشناختى بيجيده و به درستى درك نشده است كه ميليونها نفر را در دنيا تحت تأثير قرار هدف: يُزوهش حاضر با هدف بررسى ارتباط بين اجتناب تجربى و صفات طيف اوتيسم با رفتارهاى احتكارى با نقش ميانجى شناختار هاى احتكارى انجام شد. روش: يزٔوهش حاضر توصيفى از نوع همبستگى بود و جامعه آمارى آن را كليه دانشجويان دانشگاه آزاد شهر بيرجند در سال

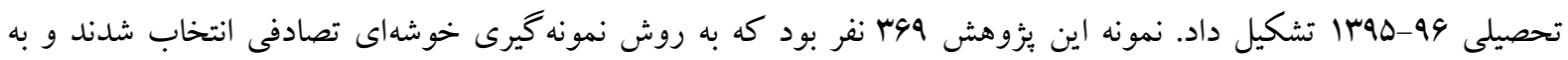

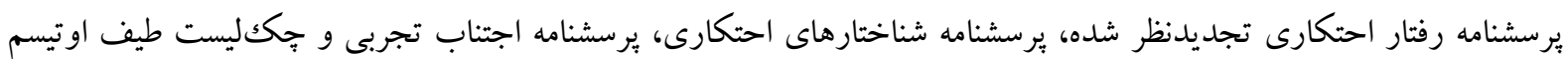

يافته ها: يافتهاى يزووهش نشان داد كه اجتناب تجربى بهطور مثبت و معنىدار با جنبههاى احتكار رابطه دارد، درحالى كه صفات

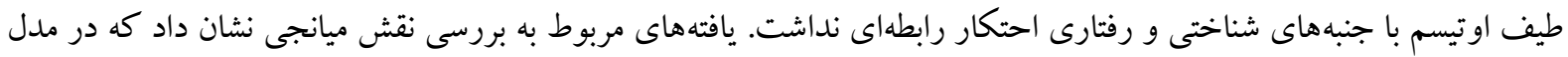
يُشنهادى فقط متغير اجتناب تجربى نقش ميانجى دارد.

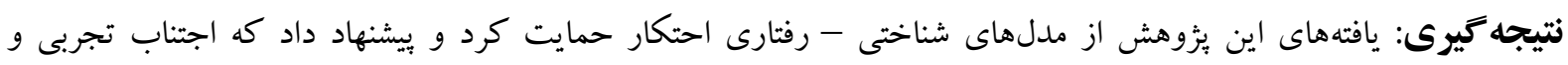

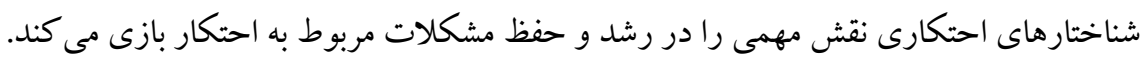

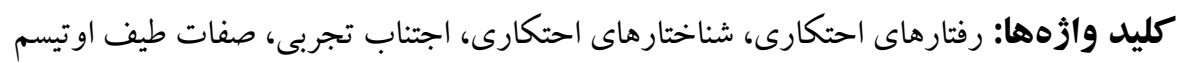


متعلقاتشان \دارند و بهعنوان نتيجه جنين باورهايى دور

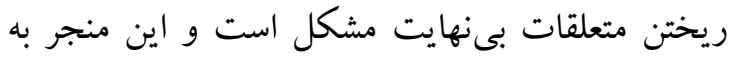
الكوهاى رفتار اجتنابى مىشود (ويتون و همكاران،

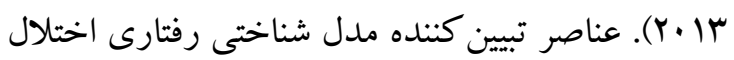

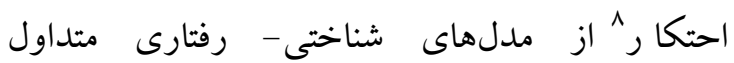
اختلالات اضطر ابى و اختلال طيف وسواسى - اجبارى تبعيت مى كنند. اين مدلها بر رفتارهاى اجتنابى بهعنوان مكانيزم هاى زيربنايى حفظ طولانىمدت نشانغان

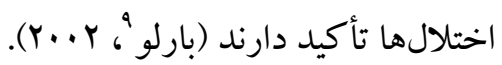
اجتناب تجربى سازهاى از حوزه نظريه تعهد و بذيرش

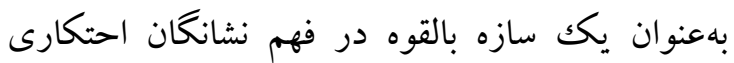
است. شواهدى وجود دارد كه اجتناب تجربى در نشانگان احتكارى نقش مهمى دارد و مطالعات متعدد نقش اجتناب تجربى را در بيشبينى نشانگان احتكارى

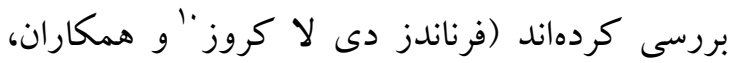
rا.r، ويتون و همكاران، 11+r، ويتون و همكاران، rا.rY). در يكك مطالعه ويتون و همكاران (r.Y) كزارش كردند كه اجتناب تجربى نشانگان احتكارى و بهطور خاص جمع آورى افراطى و رفتارهاى به انباشت،

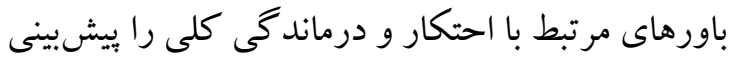

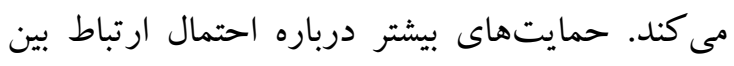

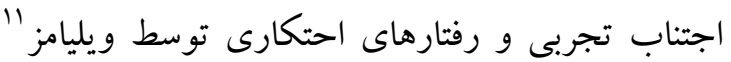

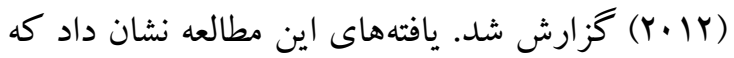

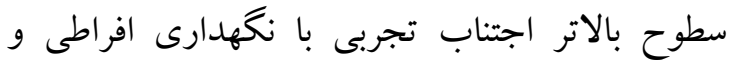
خريد اجبارى مرتبط بود. همجنين شواهد يُوهشى غيرمستقيم بر ارتباط بين اجتناب تجربى و رفتارهاى احتكارى اشاره داشتهاند. براى مثال در دو مطالعه مجزا كزارش شد كه احتكار به شدت با حساسيت يذيرى به اضطراب (تمايل به احساس ترس بدنى مرتبط با

${ }^{7}$.possessions

${ }^{8}$.cognitive-behavioral model of hoarding

${ }^{9}$.Barlow

${ }^{10}$.Fernandez de la Cruz

${ }^{11}$.Williams

\section{مقلdod} احتكار 'كه عبارت از نخهدارى و ناتوانى براى دور

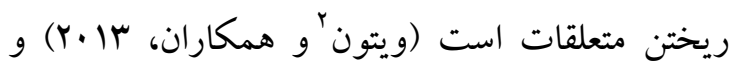

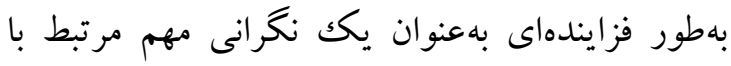
سلامت عمومى تشخيص داده مىشود، زمانى بهعنوان

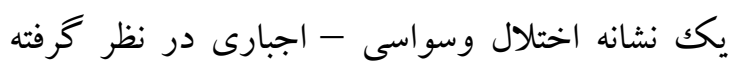
مىشود، اما بيكره فزايندهاى از شواهد نشان مىدهد كه احتكار يكك اختلال متمايز است (يرتوزا؟ّو همكاران،

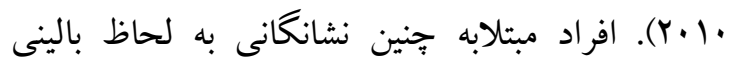
نقصهاى معنىدارى را در كاركرد اجتماعى، خانوادگى، اقتصادى و شغلى نشان مىدهند (تولين و و

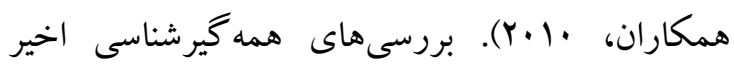
نشان مىدهد كه مشكلات احتكارى ممكن است در جمعيتهاى عمومى نيز بهطور شخفتانگيزى شايع

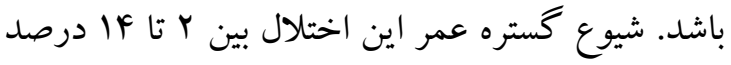

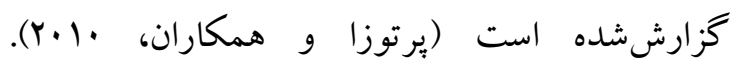
يخوهشها درباره طبقهبندى و نشانهشناسى اختلال احتكار نشان مىدهد كه احتكار احتمالاً يك سازه جندبعدى است و در طول بيوستارى در گروههاى

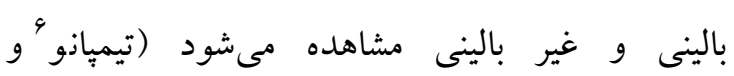
همكاران، رويكرد نظرى جامعتر درباره مشكلات احتكارى با هاب استفاده از مؤلفهاى مدلهاى شناختى رفتارى قابلبررسى است (استكيتى و فراست، ب..r). اين

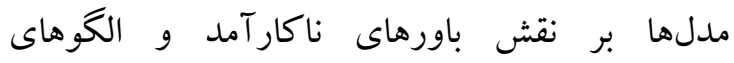

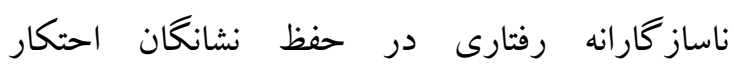
تأكيددارند. عنصر كليدى اين مدلها اين است كه افراد احتكارى باورهاى ناكار آمدى درباره معنى و اهميت

\footnotetext{
${ }^{1}$.Hoarding

${ }^{2}$.Wheaton

${ }^{3}$.Pertusa

${ }^{4}$.Tolin, DF., Frost, RO., Steketee

${ }^{5}$.nosology

${ }^{6}$.Timpano
} 
عادى ميزان بالاترى از نشانگگان احتكارى را گزارش مى كنند. همبِنين در مشاهدات بالينى مشخص شيده است كه مبتلايان به اوتيسم و اختلال احتكار مشكلات رفتارى مشابهى ازجمله انزواى اجتماعى، الخوهاى شخصى مشابه نظير شخصيت وسواسى - اجبارى و اختلال شخصيت اسكيزوتاييال را نشان مىدهند

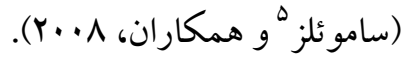

براساس آنجه در بالا اشاره شد نياز فوقالعادهاى براى شناسايى فاكتورهاى يشبينى كنتده رفتارهاى احتكارى وجود دارد؛ زيرا فاكتورهاى غالبتر مىتوانند بهمنظور افزايش كارايى مداخلات درمانى

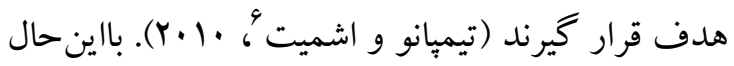
بالين حال مدلهاى شناختى - رفتارى درباره نشانگان احتكارى فرض مى كنند كه نشانگان احتكارى مى تو اند تحت تأثير باورهاى خطا، نقص در يردازش اطلاعات، الخوهاى تقويتى و تفاوتهاى فردى متنوع باشند

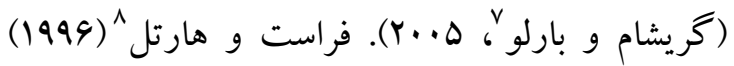
معتقدند كه الكوهاى شناختى رفتارى احتكار جهار مؤلفه كليدى دارد كه در سببشناسى و ظهور تمايلات احتكارى سهم زيادى دارند و اين عوامل عبارت هستند از: كاركرد اجرايى ضعيف، باورهاى اشتباه درباره ماهيت متعلقات و خود، دلبستخى به اشياء و اجتناب

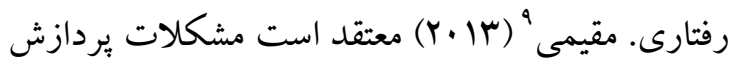
يردازش شناختى كه با رفتارهاى احتكارى مرتبط است توجه، طبقهبندى كردن، حافظه، استفاده از اطلاعات براى نتيجه گيرى و تصميم گيرى را در برمى گيرند.

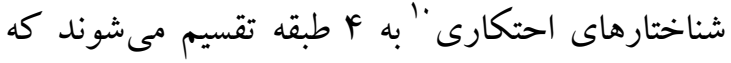
عبارتاند از دلبستكى فزاينده هيجانى به متعلقات،

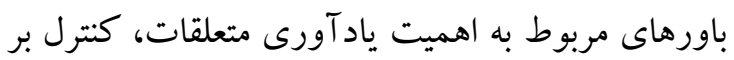

برانگيختخى اضطرابى) كه با اجتناب تجربى همبسته است (اجتناب از احساسهاى بدنى درونى) ارتباط دارد

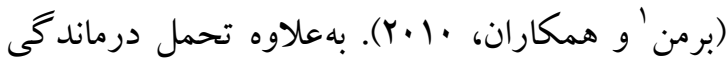
كه مشابه با اجتناب تجربى است و به ظرفيت فرد براى ايستادن در برابر رويدادهاى هيجانى منفى اشاره دارد بهنوان فاكتور آسيبيذير براى نشانگان احتكار

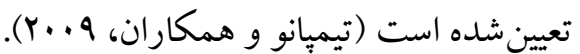
اوتيسم يا اختلال طيف اوتيسم بهعنوان نابهنجارى و رشد اجتماعى و ارتباطى و در كل با رفتارهاى تكرارى و علايق محدود مشخص مىشود (انجمن روانيزشكى

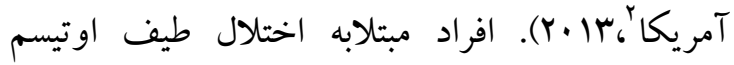
علايق شديد و محدودشدهاى دارند و اين مىتواند منجر به جستجو و جمع آورى محرككهاى مطلوب شود. بهعلاوه آنها در مقايسه با گروههاى عادى بهى سطوح بالاترى از رفتارهاى احتكارى و نخهدارى را

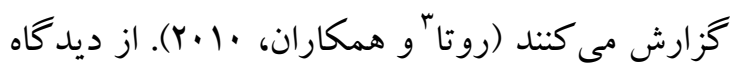
يديدار شناختى در افراد با اختلال طيف اوتيسم سيماى بالينى خاصى كه در مبتلايان به اختلال احتكار مشاهده مىشود ازجمله نقص در نظريه ذهن مرتبط با سلامت،

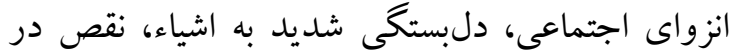
بينش و خود ادراكى و مشكلات مربوط به ايجاد

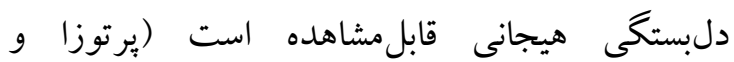
همكاران، Y (Y. Y). همجنين افر اد با اختلال طيف اوتيسم و افراد مبتلابه احتكار نقصهاى شديد در كاركرد اجرايى ازجمله مشكل عدم درگيرى با محركها، بىتوجهى، تكانش وپذيرى و بيش فعالى را نشان

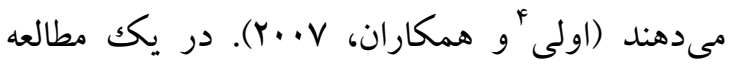

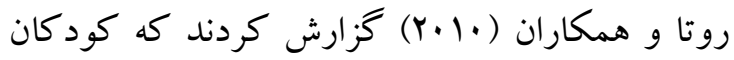
مبتلابه سندرم آسبر گر در مقايسه با گروههاى كنترل

\footnotetext{
${ }^{1}$.Berman

2.American Psychiatric Association

${ }^{3}$.Ruta

${ }^{4}$. Olley
} 


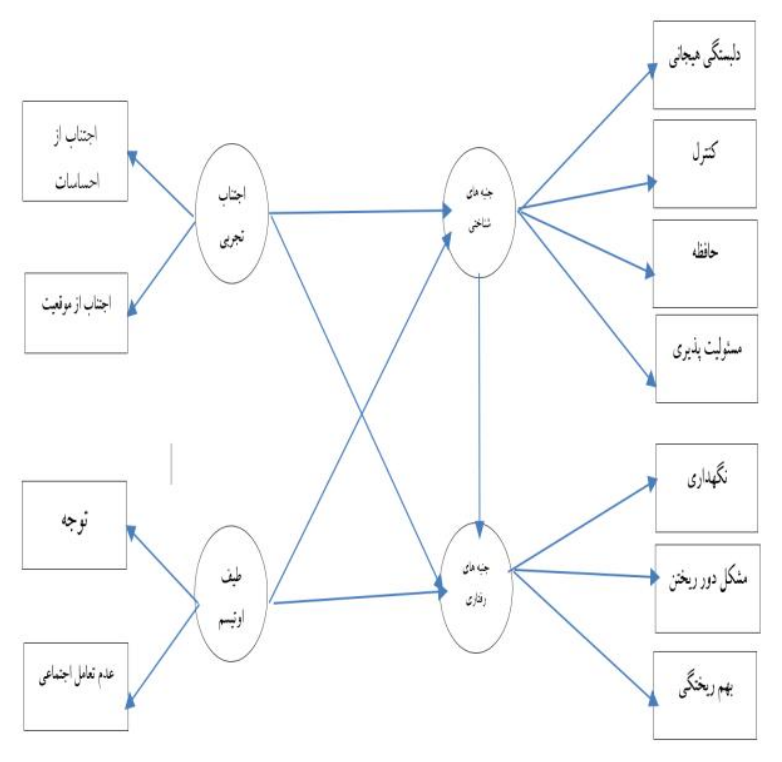

شكل ا مدل مفهومى ثزوهش

روش

بثزوهش توصيفى از نوع همبستخى است كه با رويكرد

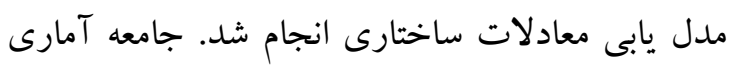

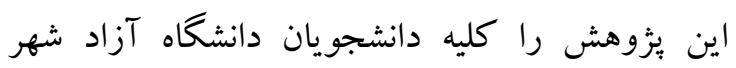
بيرجند در سال تحصيلى 9ه-ههبا كه تعداد آنها

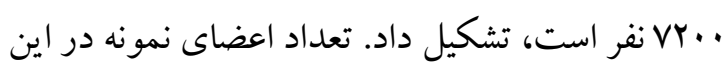
يُزوهش با توجه به حجم جامعه (...

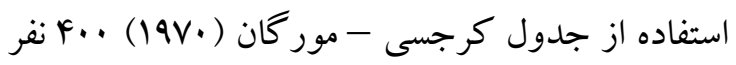
بر آورد گرديد. براى انتخاب نمونه از روش نمونه گيرى خوشهاى تصادفى استفاده شد. ابتدا ليست رشتهاى

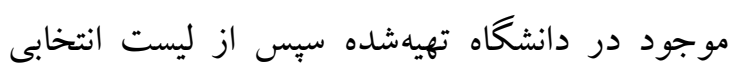
بهصورت تصادفى ده رشته و از هر رشته دو كلاس انتخاب شدند و به ابزارهاى بُوهش بِ بِاسخ دادند.

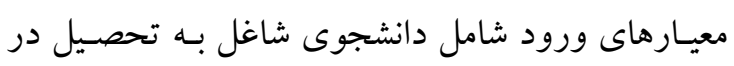

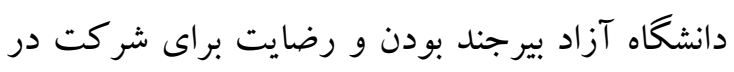

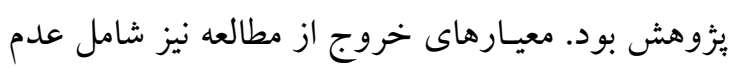
تمايل به شركت در مطالعه يـا نقص در تكميل

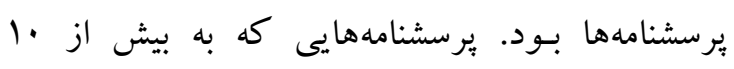
درصد سؤالات پياسخ نداده بودند از تحليلها كنار

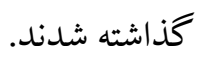

متعلقات و مسئوليتيذيرى براى استفاده درست از

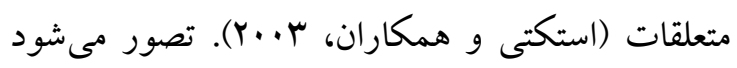
كه شناختارهاى احتكارى در رشد و حفظ رفتارهاى احتكارى نقش كليدى را بازى مى كنند و مشخص شهده

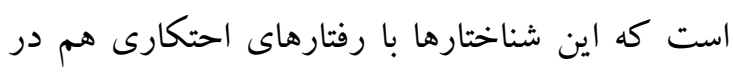
نمونهاى بالينى و هم در نمونهاى غير بالينى مرتبط

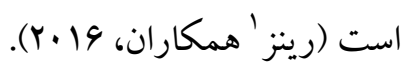

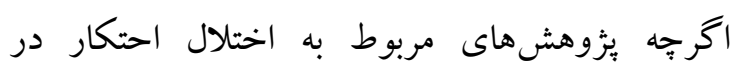

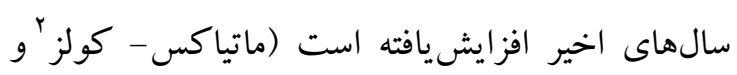

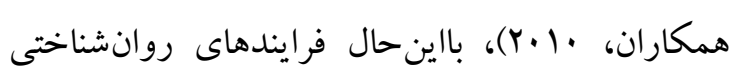
درگير در ايجاد مشكلات ناتوانكننده مرتبط با اين اختلال هنوز بهطور كامل روشن نشدهاند. بهعلاوه

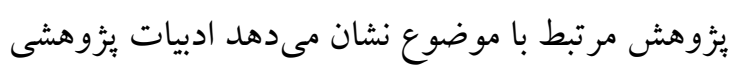
مربوط به سببشناسى نشانگان احتكارى در خارج از

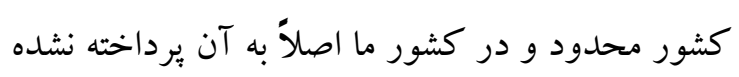

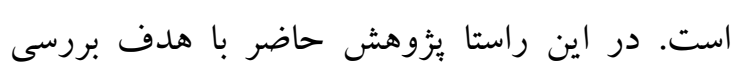
نقش ميانجى شناختارهاى احتكارى در ارتباط بين اجتناب تجربى و صفات طيف اوتيسم با رفتارهاى

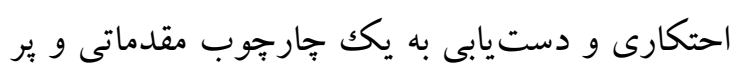
كردن خلأ ئزوهش مربوط به اين زمينه در يكك جمعيت

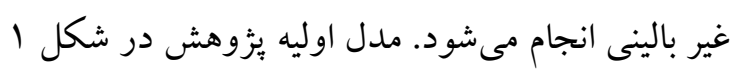

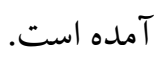


باورهاى مرتبط با نشانهشناسى احتكار را دربرمى گيرد. اين شاخصها شامل F خرده مقياس دلبستخى هيجانى،

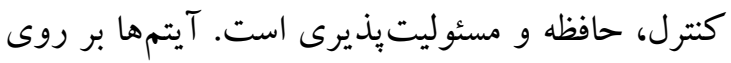
يكك مقياس V درجهاى از اصلاً تا خيلى زياد درجهبندى لئى

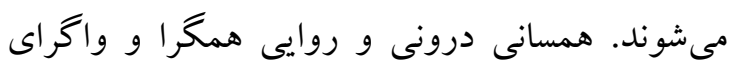

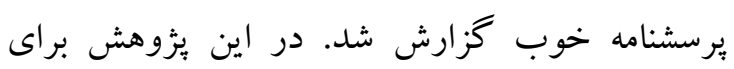
تعيين روايى برسشنامه از تحليل عاملى اكتشافى و براى برى بردي بررسى بايايى برسشنامه از آلفاى كرونباخ استفاده شد. نتايج تحليل عاملى اكتشافى ساختار جهار عاملى رو

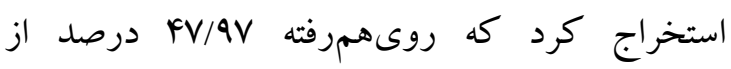

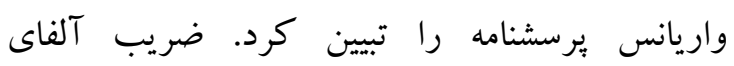

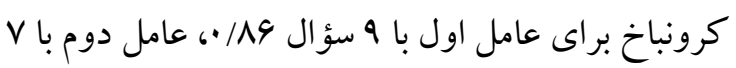

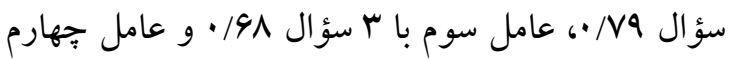

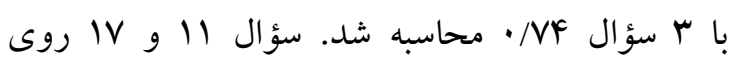

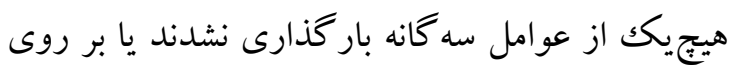
عامل هاى مذكور بار عاملى كمتر از •^/ • داشتند.

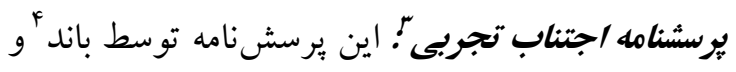

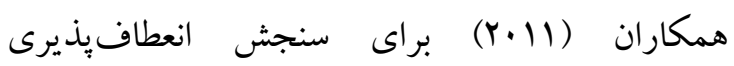
روانشناختى، بلويزه در ارتباط با اجتناب تجربى و تمايل به درگيرى در عمل با وجود افكار و و بهاب احساسهاى ناخواسته تدوينشده و داراى V سؤال است. سؤالهاى اين برسشنامه بر اساس ميزان توافق

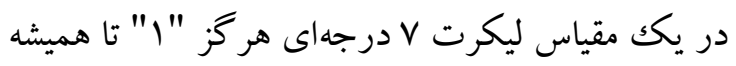

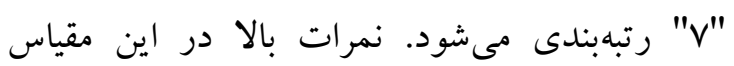

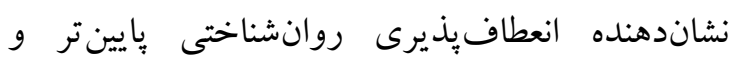

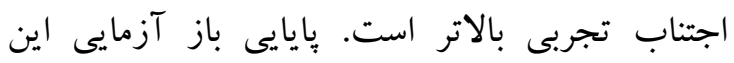

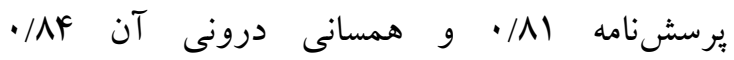
بهدست آمده است. در ايران نيز ضريب بايايى آلفاى كرونباخ برسشنامه يذيرش و عمل وير ايش دوم

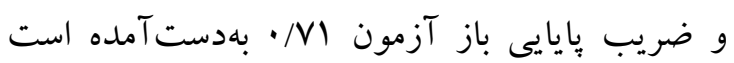


يافته ها

از مجموع F. P برسشنامه توزيعشده واجد ملاككهاى لازم جهت تجزيهوتحليل تشخيص

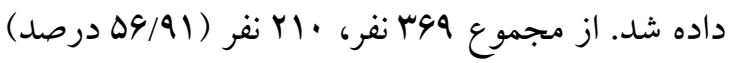

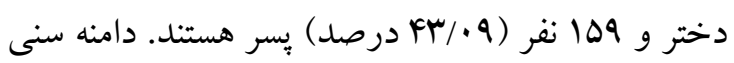

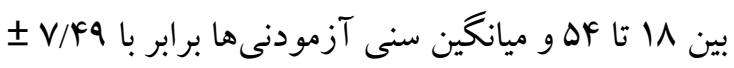

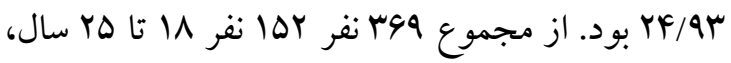

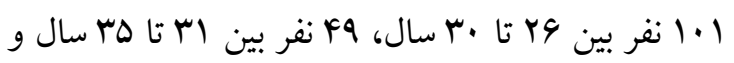
$9 V$ نفر بالاى هـ سال سن دارند.

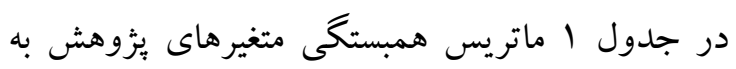
همراه شاخصهاى توصيفى متغيرها شامل ميانگين و انحر اف استاندارد ارائه شد. بر اساس نتايج حاصل از جدول بيشترين همبستگى مشاهدهده بين جنبه هاى رفتارى با جنبه إى شناى شناختى احتكار مشاهده شد، اين همبستخى مثبت و در سطح

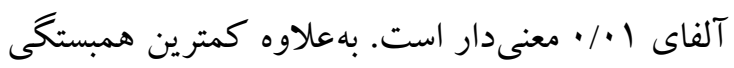
مشاهدهده بين اجتناب از احساسات با توجه مشاهده شد، اين همبستخى نيز مثبت و غير معنىدار است. براى بررسى مفروضه نرمال بودن دادههاى توزيع از

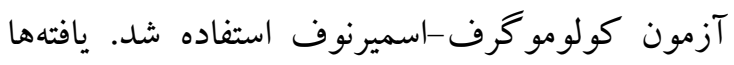
نشان داد هيجيكك از متغيرهاى بُزوهش از مفروضه

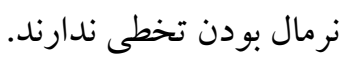

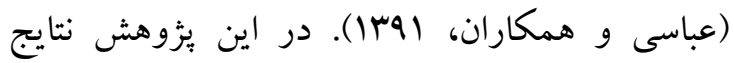
تحليل عاملى اكتشافى ساختار دوعاملى را استخراج كرد كه روىهمرفته برسشنامه را تبيين كرد. اين دو عامل اجتناب از از احساسات و اجتناب از موقعيت نام كذارى شدند. ضريب آلفاى كرونباخ براى عامل اول با ث سؤال سه/ • و براى عامل دوم با ب سؤال V9/ • محاسبه شد. جككليست طيف اوتيسم'! : جككليست طيف اوتيسم

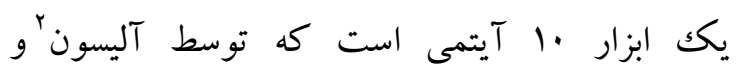

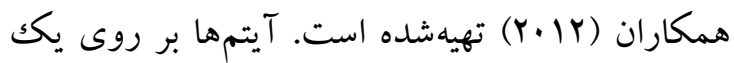

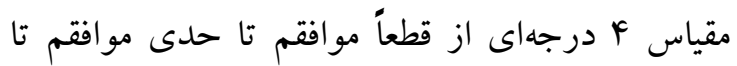
حدى مخالفم و قطعاً مخالفم درجهبندى مىشوند. اين

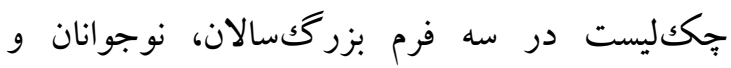
كود كان تهيه شده است. آيتمهاى اين جّك ليست در هـ كروه توجه به جزئيات، تغيير توجه ب، ارتباطى، تخيل و و

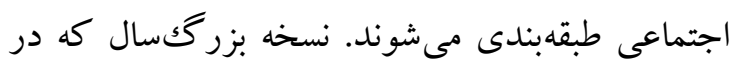
اين ئزوهش استفاده خواهد شد با نقطه برش 9 و

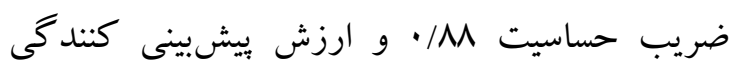
مثبت هA/· تعيين شد. بايايى به روش همسانى درونى

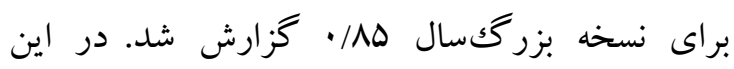
بُزوهش براى تعيين روايى برسشنامه از تحليل عاملى برلى

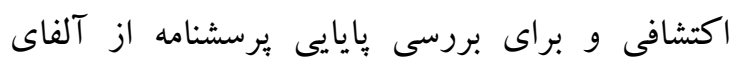

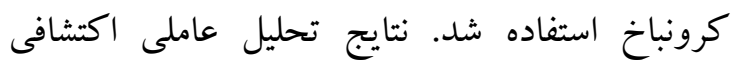
ساختار دوعاملى رو استخراج كرد كه روىهمرفته

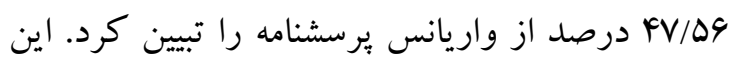
دو عامل توجه و عدم تعامل اجتماعى نام گذارى شدند.

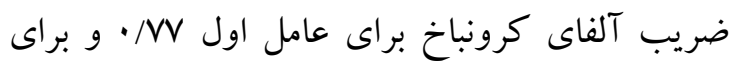

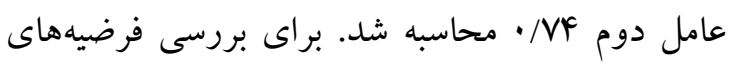
يثزوهش ضريب همبستخى بيرسون و تحليل معادلات

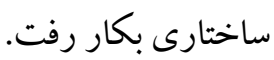




\section{جدول 1 ماتريس همبستغى متغيرهاى يزوهش}

\begin{tabular}{|c|c|c|c|c|c|c|}
\hline شناختى احتبه هاى & رفتارى احتبهاى & عدم تعامل & توجه & اجتناب از & اجساسات اجنات & متغير \\
\hline & & & & & 1 & اجتناب از احساسات \\
\hline & & & & 1 & $\cdot / \& V^{* * *}$ & اجتناب از موقعيت \\
\hline & & & 1 & $\cdot / 1 r^{* * * *}$ & $\cdot / \cdot \Delta$ & توجه \\
\hline & & 1 & .1 .9 & $\cdot / \cdot v$ & $\cdot / 11^{*}$ & عدم تعامل اجتماعى \\
\hline & 1 & $\cdot / I V^{* * * *}$ & $\cdot / 19^{* * * *}$ & $\cdot / \mu F^{* * * *}$ & $\cdot / r q^{* * * *}$ & جنبه هاى رفتارى احتكار \\
\hline 1 & $\cdot / \& q^{* * * * *}$ & .1 .9 & $\cdot / 1 V^{* * * * *}$ & $\cdot / A Y^{* * * * *}$ & $\cdot / \mu \Lambda^{* * * *}$ & جنبه هاى شناختى احتكار \\
\hline$V \Delta / Y V$ & $\Delta F / I F$ & $1 / 10$ & $r / 9 \mathrm{~V}$ & $V / 9 \Lambda$ & $1 \cdot /$ H $^{4}$ & ميانتين \\
\hline $1 \mathrm{~N} / \mathrm{IV}$ & $I Y / M F$ & $\cdot / \mathrm{VG}$ & $1 / 19$ & Y/Vq & $r / 19$ & انحراف استاندارد \\
\hline
\end{tabular}

جنبههاى شناختى احتكار مثبت و معنىدار (191. و بر رفتارهاى احتكارى مثبت و غير معنىدار است

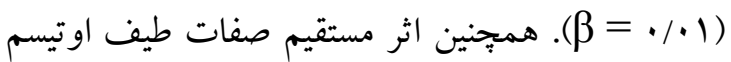
بر جنبهاى شناختى احتكار (1/N / احتكارى (FV) • م مثبت و غير معنىدار است. بهعلاوه جدول نشان مىدهد كه جنبههاى شناختى احتكار بهطور مثبت و معنىدار بر رفتارهاى احتكارى

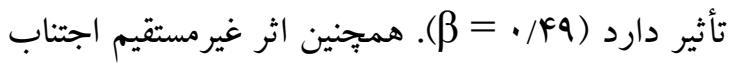
تجربى بر جنبههاى رفتارى احتكار (•r/. معنىدار است، درحالى كه اثرات غيرمستقيم صفات طيف اوتيسم بر جنبهاى رفتارى احتكار (q./. مثبت و غير معنى مار است.

بهمنظور بررسى برازش مدل مفهومى با دادههاى

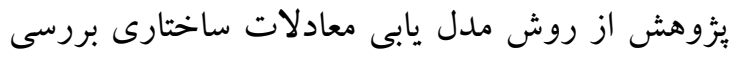

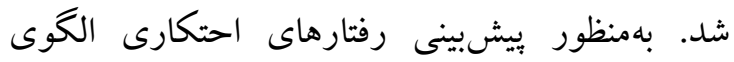
مفهومى ييشنهاد شده از طريق روش مدل يابى معادلات ساختارى بررسى شد. روش SEM از آنجهت انتخاب شد كه اين رويكرد از تكنيكهاى ترتيبى حداقل مجذور برتر بوده و مىتواند بهنظور ارزيابى كفايت

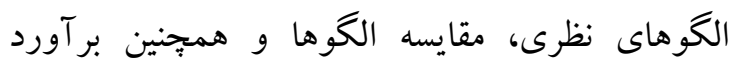
يارامترهاى الكو در بين گروههاى مختلف مورداستفاده

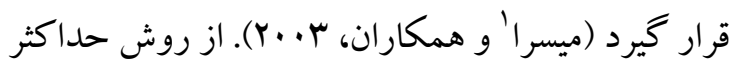

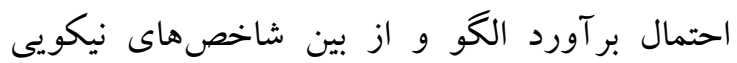

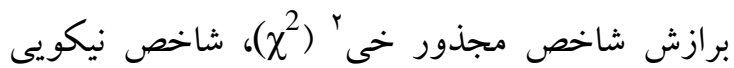

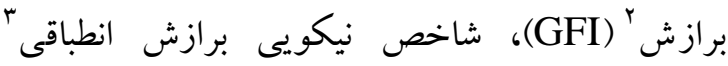

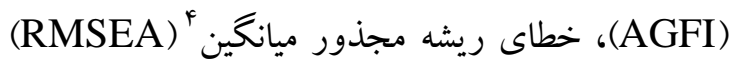
و ... براى برازش الكو استفاده شد. ضرايب مسير مدل فرضى در شكل ا و ضرايب مسير متغيرهاى برونزا و درونزا در جدول ب ارائهده است. طبق دادههاى شكل بالا اثر مستقيم اجتناب تجربى بر بروبر

\footnotetext{
${ }^{1}$.Misra

. Goodness of Fit Index

${ }^{3}$.Adjusted Goodness of Fit Index

${ }^{4}$.Root Mean Square Error
} 


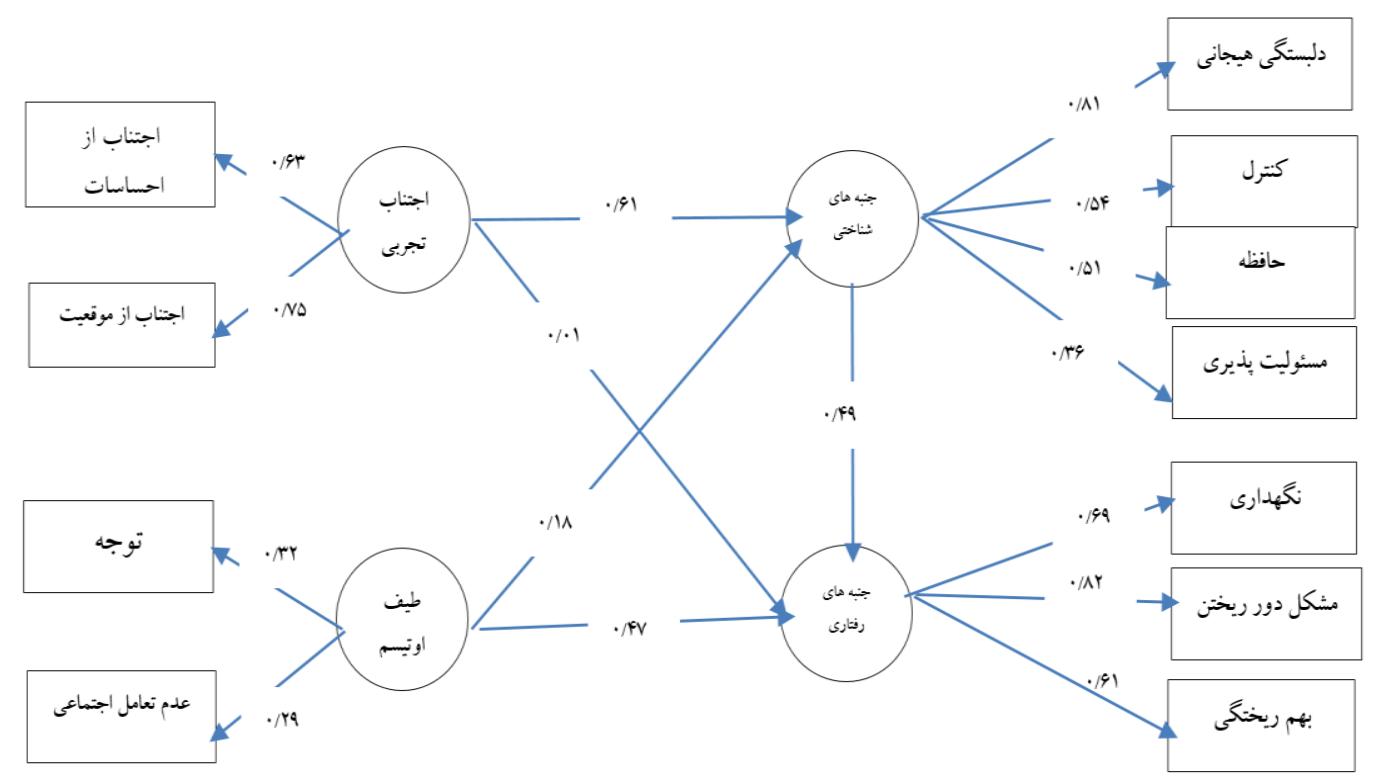

Chi-square $=115.81, \mathrm{df}=38, \mathrm{p}$-value $=0.000, \mathrm{RMSEA}=0.075$

جدول r ضرايب مسير متغيرهاى برونزا و درونزا

\begin{tabular}{|c|c|c|c|c|c|c|}
\hline معنى سطح & شاخص & استاندارد & ضرايب & ملاكك & بيشبين & \\
\hline$<\cdot / \cdot 1$ & $\Delta / \Delta F$ &.$/ 11$ & .191 & جنبهاى شناختى احتكار & اجتناب تجربى & \multirow{5}{*}{ مستقيم اثرات } \\
\hline$>\cdot / \cdot \Delta$ & $\cdot / \cdot r$ & $\cdot / I V$ & $\cdot / \cdot 1$ & جنبههاى رفتارى احتكار & & \\
\hline$>\cdot / \cdot \Delta$ & $1 / \cdot v$ & $\cdot / I V$ & $\cdot / 11$ & جنبههاى شناختى احتكار & \multirow[t]{2}{*}{ صفات طيف او تيسم } & \\
\hline$>\cdot / \cdot \Delta$ & $1 / 91$ & $\cdot / Y F$ & $\cdot / F V$ & جنبههاى رفتارى احتكار & & \\
\hline$<\cdot / \cdot 1$ & $r / W V$ & $\cdot / \Lambda$ &.$/ 4 q$ & جنبههاى رفتارى احتكار & جنبههاى شناختى احتكار & \\
\hline$<\cdot / \cdot 1$ & $r / l$. & $\cdot / l F$ & $\cdot \pi$ & از طريق جنبههاى شناختى احتكار & اجتناب تجربى بر جنبههاى رفتارى احتكار & \multirow[b]{2}{*}{ غير مستقيم اثر } \\
\hline$>\cdot / \cdot \Delta$ & $1 / \% \Lambda$ & .1 .9 &.$/ \cdot 9$ & از طريق جنبههاى شناختى احتكار & صفات طيف اوتيسم بر جنبههاى رفتارى & \\
\hline
\end{tabular}

در مقايسه با قبل از اصلاح از شاخصهاى برازش بهترى برخوردار بود. بر اساس شاخصهاى برازش

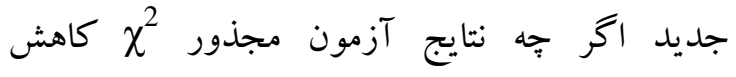
قابلتوجهى نشان داد، اما مشخص شد بين الكوى بيشنهادشده و مشاهدهشه برازش وجود ندارد ( ( •/.

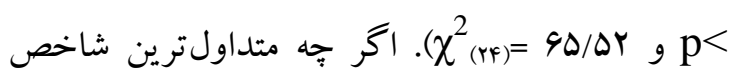

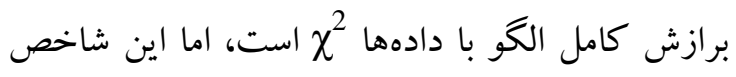
داراى دو محدوديت است: اولاً اين آماره برازش كامل آل
با توجه به غير معنىدار بودن تعدادى از مسيرهاى مدل فرضى، بيرايش و اصلاح مدل بر اساس شاخص هاى اصلاح صورت كرفت. يس از حذف مسير مستقيم و غيرمستقيم صفات طيف او تيسم به جنبه هاى شناختى و رفتارى احتكار و مسير مستقيم اجتناب تجربى به احتكار رفتارى به دليل غير معنىدار بودن اين اصلاح

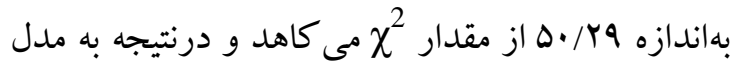
برازش يافته نزديككتر مىشود. برونداد يس از اصلاح 
برازش مقايسهاى CFI برابر با AVI/، شاخص برازش

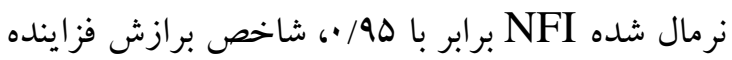

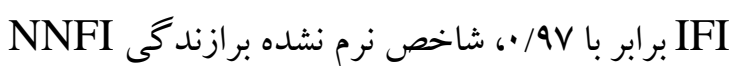

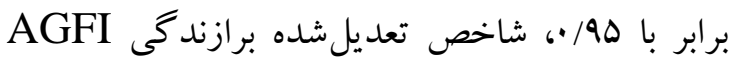

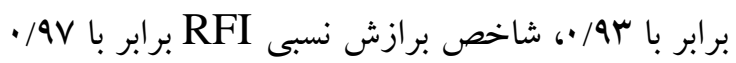

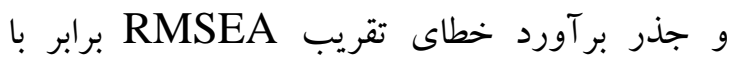

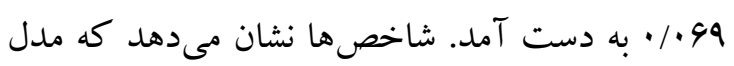

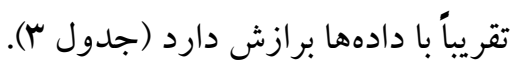

الكو با دادهها را بررسى مى كند، اين درحالى كه است

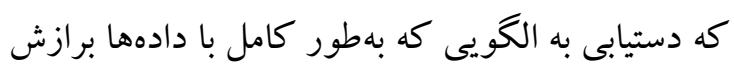

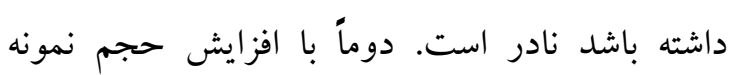
احتمال معنىدارى شاخص بيشتر مىشود؛ بنابراين

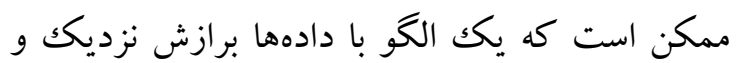
قابلقبولى داشته باشد، اما در مدل دستيابى به يك بك الك مقدار

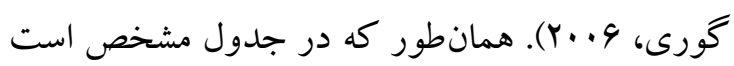

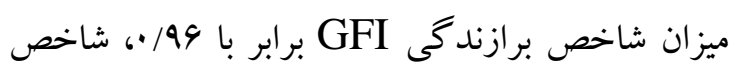

\begin{tabular}{|c|c|c|c|c|}
\hline نتيجه & ميزان در مدل & جه زمانى مدل برازنده است؟ & نام آزمون & رديف \\
\hline رد & $9 \Delta / \Delta r$ & معنادار نباشد. & $\begin{array}{l}\text { مجذور خى }{ }^{r}{ }^{2} \\
\chi^{2}\end{array}$ & 1 \\
\hline 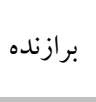 & .1 .99 & اكر كوجگكتر از هـ/• باشد. & جذر بر آورد خطاى تقريب & $r$ \\
\hline 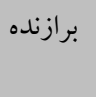 &.$/ 99$ & بايد بزرگكتر از • ه/ • باشد. & $\begin{array}{c}\text { شاخص برازندگى } \\
\text { GFI }\end{array}$ & $r$ \\
\hline 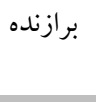 & $\cdot / 9 V$ & بايد بزرگك تر از •9/ • باشد. & شاخص برازش مقايسهاى & $\varphi$ \\
\hline 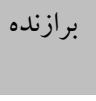 & $\cdot / 9 \Delta$ & بايد بزرگت تر از • ه/ • باشد. & شاخص برازش نرمال شده & $\Delta$ \\
\hline 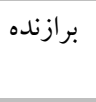 & $\cdot / 9 \vee$ & بايد بزرككتر از • ه/ • باشد. & $\begin{array}{c}\text { شاخص برازش فزاينده } \\
\text { IFI }\end{array}$ & q \\
\hline 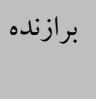 & $\cdot / 90$ & بايد بزرككتر از • ه/· باشد. & $\begin{array}{c}\text { شاخص نرم نشده برازندكى } \\
\text { NNFI }\end{array}$ & $\checkmark$ \\
\hline 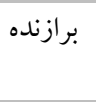 & $\cdot / 94$ & بايد بزرككتر از •ه/ • باشد. & شاخص تعديلشده برازندگى & $\Lambda$ \\
\hline 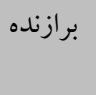 & $\cdot / 9 V$ & بايد بزرككتر از •ه/ • باشد. & شاخص برازش نسبى & 9 \\
\hline
\end{tabular}

بهعلاوه آنها تأكيد مى كند كه مقادير كمتر از هـ/.

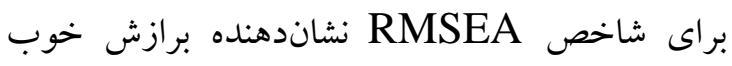

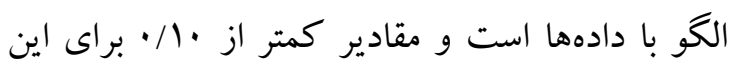
شاخص برازش قابل قبول الكو با دادهها را نشان مىدهد.
براون و كودكى (199ه، به نقل از خدايى و شكرى،

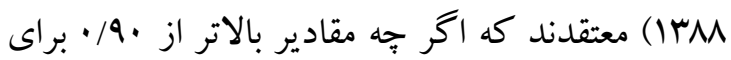
AGFI و CFI،GFI

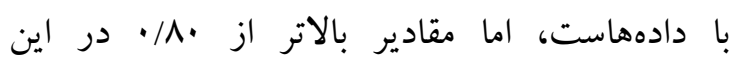

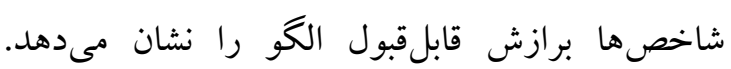




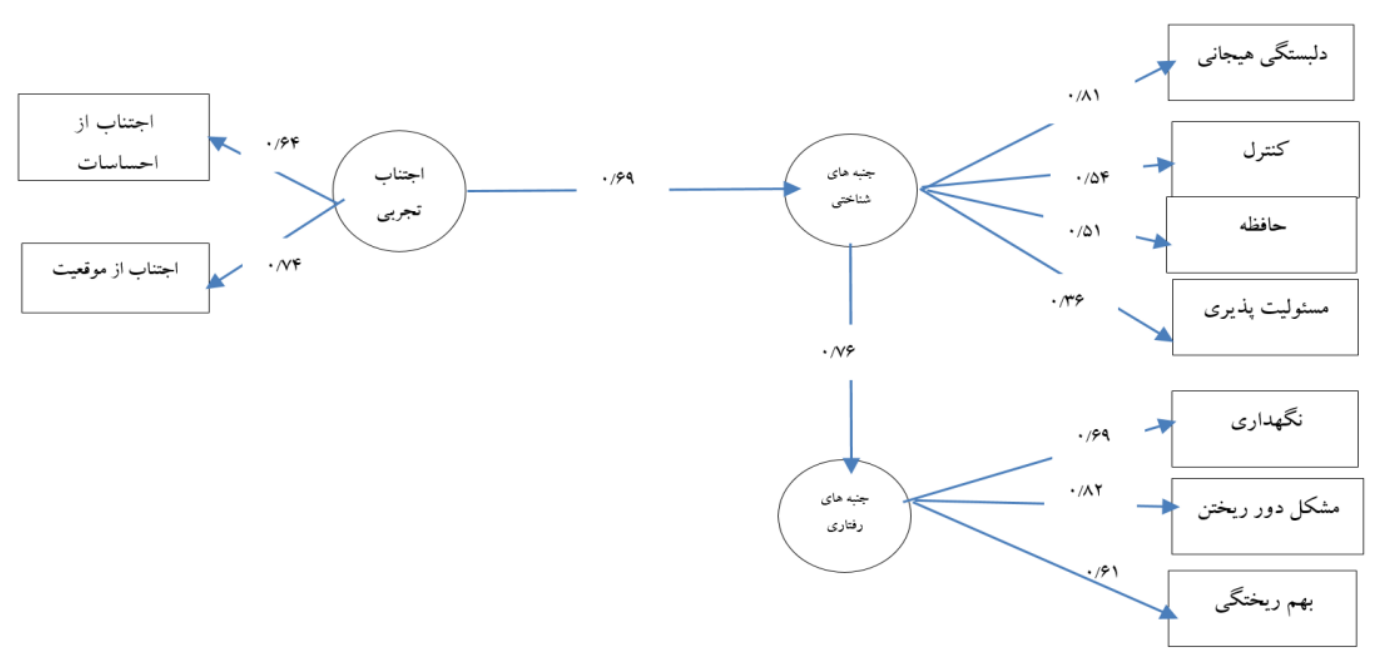

Chi-square $=65.52, \mathrm{df}=24, \mathrm{p}$-value $=0.001, \mathrm{RMSEA}=0.069$

شكل r ضرايب مسير مدل اصلاحشده در مدل يابع رفتارهاى احتكارى

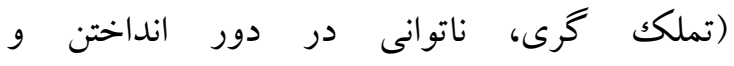

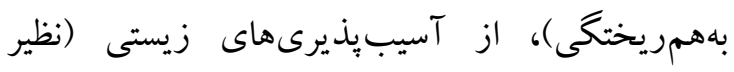
يافتهاى بيزوهش نشان داد كه اجتناب تجربى بهطور

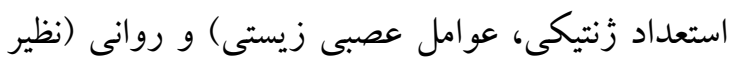

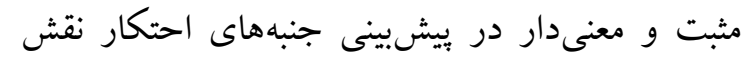
تجربيات اوليه، خلق منفى، صفات شخصيتى) كه بر دارند. درحالى كه صفات طيف اوتيسم با جنبه لهاى بردازش اطلاعات تأثير مى گذارند (نظير اختلال در شناختى و رفتارى احتكار رابطهاى نداشت.

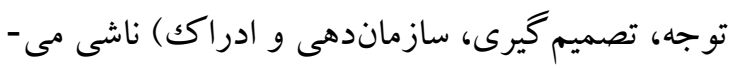
شوند. اين آسيب يذيرىها باعث باورهاى نادرست فرد

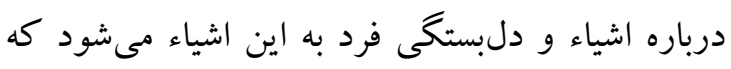
اين مسئله بهنوبه خود هم ياسخ هاى عاطفى مثبت و هم ياسخهاى عاطفى منفى را در فرد موجب مىشود و به

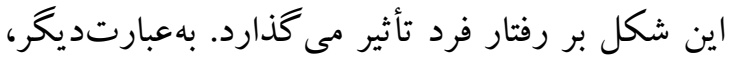
عواطف منفى نظير اضطراب، احساس كُاه و غم منجر به رفتارهاى اجتنابى (نخهدارى از اشياء بهمنظور اجتناب

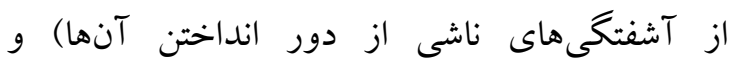

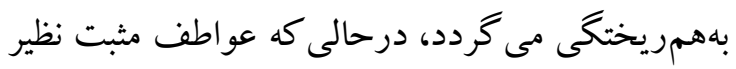

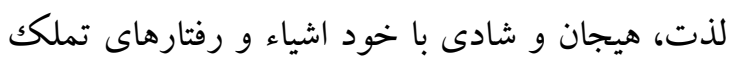

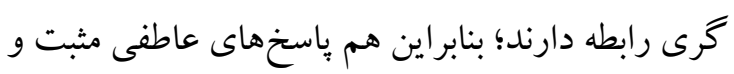

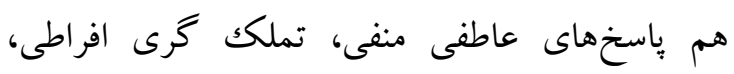
نكهدارى از اشياء و به همريختخى را تقويت مى كنند

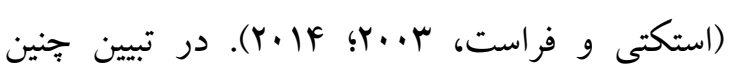


كمترى در افراد نرمال يا داراى نمره بايين در نظاممندى

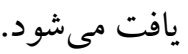

بهعلاوه تحليلهاى مرتبط با نقش ميانجى جنبهاى

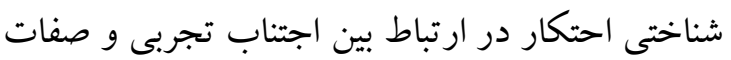
طيف اوتيسم با رفتارهاى احتكارى نشان داد كه در مدل بيشنهادى فقط متغير اجتناب تجربى دراينارتباط

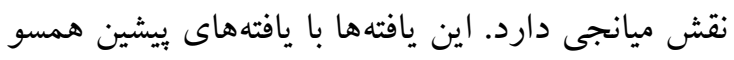

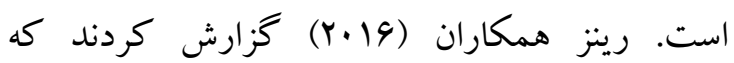
شناختارهاى احتكارى در رشد و حفظ رفتارهاى احتكارى نقش كليدى را بازى مى كنند و مشخص شده

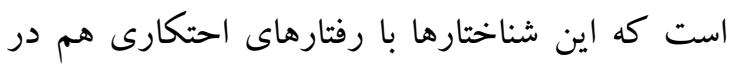
نمونههاى بالينى و هم در نمونهاى غير بالينى مرتبط است. ويتون و همكاران (Yll) رابطه بين شناختهاى احتكارى، اجتناب تجربى و رفتارهاى احتكارى خود

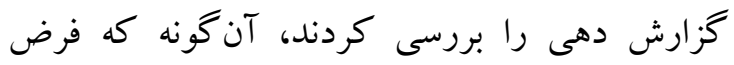
مى شد هم اجتناب تجربى و هم شناختارهاى احتكارى با نشانگان احتكارى همبسته بودند. لوى و همكاران (Y.IV) احتكارى كاهش نشانگان اختلال احتكار را در درد مدلهاى شناختى رفتارى ميانجى مى كند. در تبيين نقش ميانجى شناختارهاى احتكارى در ارتباط مداط

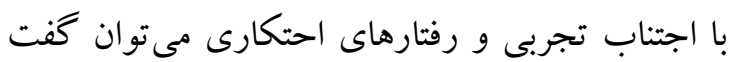
كه اجتناب مؤلفه كليدى مدلهاى شناختى رفتارى احتكار است و اين نتايج از اين مفهومسازى حمايت

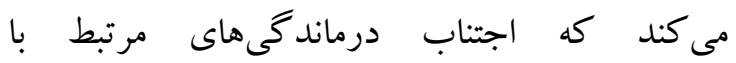
شناختارهاى تحريفشده در خصوص ضرورت و سودمندى متعلقات را كاهش مىدهد (فراست و

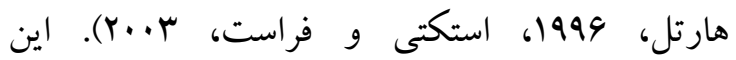
شناختارهاى تحريفشده درماندگى هاى درونى مرتبط با افكار و هيجانات منفى را شكل مىدهد (استكتى و

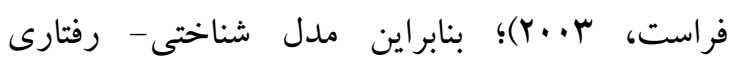
بيشبين مى كند كه افراد با اجتناب تجربى بالا

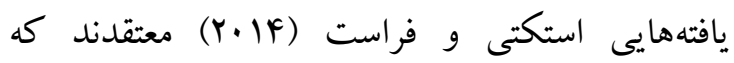
رفتارهاى مبتنى بر اجتناب نظير جمع آورى يا مشكل در دور ريختن متعلقات مورداستفاده قرار مى گيرند تا تجارب درونى منفى ناشى از شناختارهاى تحريفشده درباره متعلقات را كاهش دهند. بهعلاوه مشخص

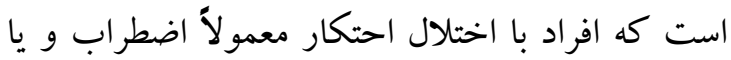
درماندگى را تجربه مى كنند و زمانى كه متعلقات را با مرتب و طبقهبندى مى كنند يا دور مىريزند احساس استيصال مى كنند. آنها ممكن است تمايلى به باقى ماندن در جنين وضعيتى نداشته باشند و تلاشهاى آكاهانهاى را براى كنترل يا فرار از اين تجارب انجام دهند، ييامد اين رفتار انباشت متعلقات در خانه است

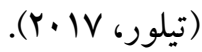
يافتهاى مربوط به رابطه بين صفات طيف اوتيسم با

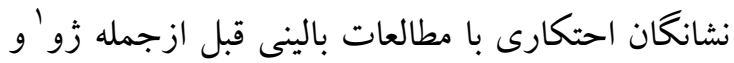

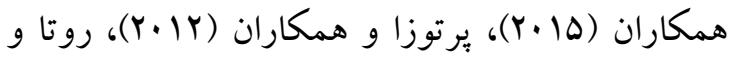

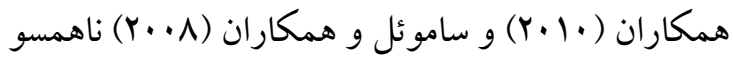
است. اين تفاوت مىتواند ناشى از اندازه كم نمونه و داشتن گروههاى بالينى در مطالعات ذكرشده باشد. ويتون (rا.بr) يك نمونه سب نفرى از افراد با اختلال احتكارى را مورداستفاده قرارداد. فرناندز دى لا كروز

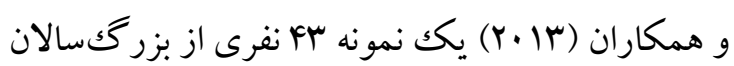
و وسواسى - اجبارى را بررسى كرد. علت ديخر اين ناهمسويى مى تواند ناشى از اين مسئله باشد كه اكثريت

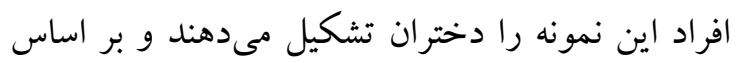

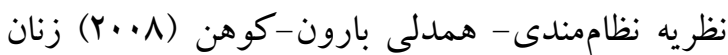
در مقايسه با مردان، اغلب نمره پايين ترى در نظاممندى كسب مى كنند؛ بنابر اين برخى از ناهنجارىهاى ساختار مغزى (ناهنجارى در نظاممندى و همدلى) كه در افراد داراى نمره بالا در نظاممندى مشاهده مىشود به ميزان 
كروههاى داراى اختلال احتكار مشكل مى كند. با توجه به محدوديتهاى ذكرشده در إزوهشهاى آتى در جمع آورى دادهها از رويكردهاى تركيبى (جند روشى)

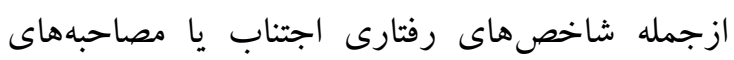

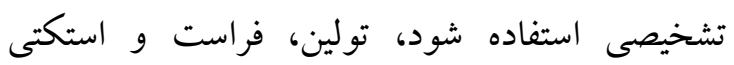

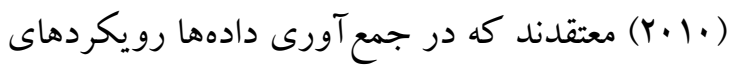
تركيبى در مقايسه با روشهاى خود كزارش دهى رواتر و قابل اعتمادترند. از آنجاكه در دهه هاى اخير در

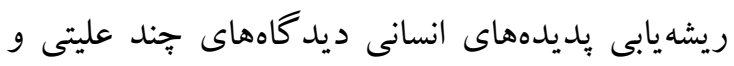

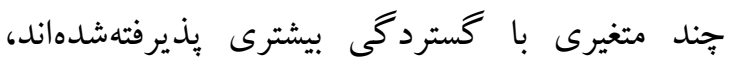

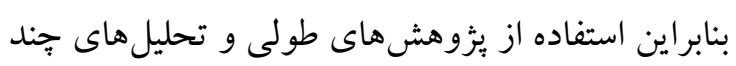

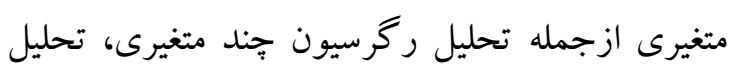
مسير و الكوى معادلات ساختارى و در نظر گرفتن

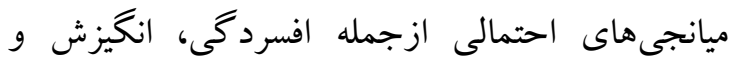

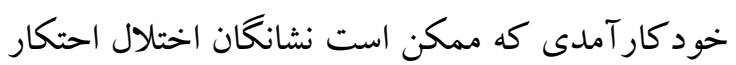
را تحت تأثير قرار دهند (لوى و همكاران، IV) امكان آزمون روابط على غير آزمايشى يا روابط

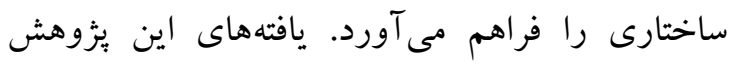
كاربردهايى در زمينه ارزيابى و درمان اختلال احتكار دارد. بر اساس يافتهاى اين مطالعه تغيير در شناختارهاى احتكارى ارتباط بين اجتناب تجربى و و

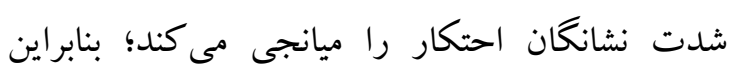
ضرورى است تا اين مكانيزم ميانجى بررسى شود و در

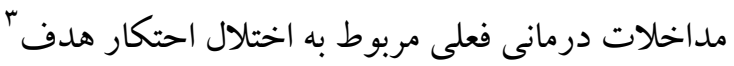
قرار گيرد. در زمينه ساخت ابزارهاى كمهزينهتر جهت فربت غربال گيرى سريع و شناسايى دانش آموزان با اجتناب تجربى در كليه مقاطع (راهنمايى، ابتدايى و دبيرستان)

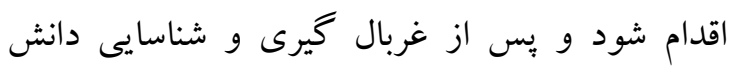
آموزان مستعد اقدامات درمانى لازم صورت كيرد.

\section{نتيجه كيرى}

${ }^{3}$-target
رفتارهاى احتكارى را بهعنوان راهبردهاى جهت مقابله

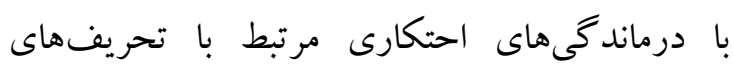

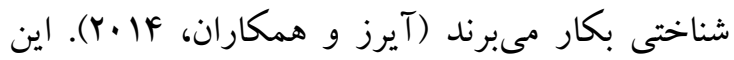

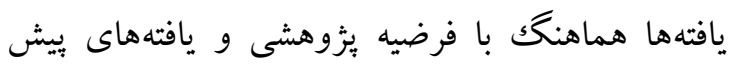

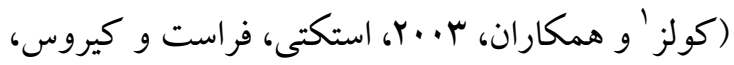

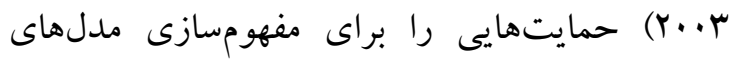
شناختى - رفتارى احتكار كه فرض مى كند باورهاى

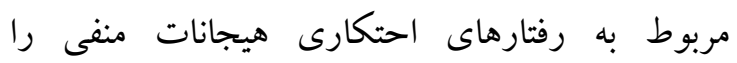
تحريك مى كند و در ادامه اين تحريك هيجانى منجر

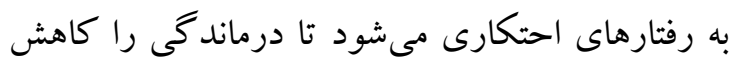
دهد، ارائه مىدهد. فرض بر اين است كه شناختارهاى

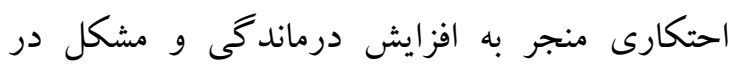
تصميم گيرى درباره دور ريختن متعلقات مى شود و اين منجر به بى سازمانى و انباشت متعلقات مىشود (استكتى دوري

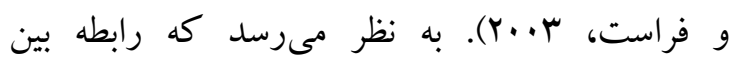
شناختارهاى احتكارى و رفتارهاى احتكارى از طريق توجه و جذابيت هيجانى كه فرد به افكارش مىدهد

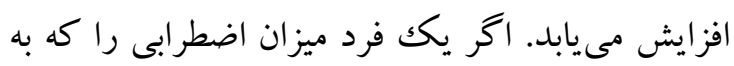

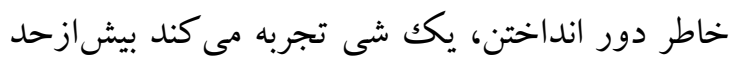

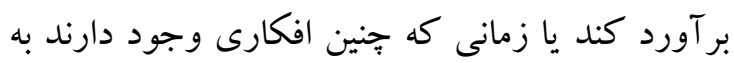
لحاظ ذهنى غمخينتر شوند، اين باعث مىشود تا لـ رفتارهاى احتكارى تقويت شود و حلقه شناخت- رفتار

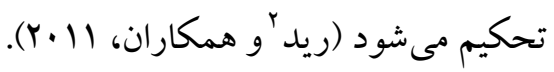
باين حال اين بزوهش داراى محدوديتهايى است. اين مطالعه بهصورت مقطعى انجام شد. فرناندز دلاكروز و و

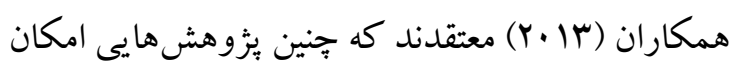
دركك كامل از روابط على بين متغيرها را فراهم

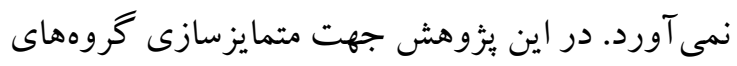
بهنجار و داراى اختلال احتكار هيج نقطه برشى در نظر كرفته نشد و اين امكان مقايسه و تعميم نتايج به 
Therapy and Experimental Psychiatry, 45(3), 408-414.

Barlow DH. (2002). Anxiety and its disorders: The nature and treatment of anxiety and panic. 2nd ed. New York: Guilford Press.

Berman NC, Wheaton MG, McGrath P, \& Abramowitz JS. (2010).Predicting anxiety: The role of experiential avoidance and anxiety sensitivity. Joumal of Anxiety Disorders, 24(1), 109-113.

Bond FW, Hayes SC, Baer RA, Carpenter KM, Guenole N, Orcutt HK, Waltz T \& Zettle DR. (2011). Preliminary psychometric properties of the Acceptance and Action Questionnaire-II: a revised measure of psychological inflexibility and experiential avoidance. Behavior Therapy, 42(4), 676-88.

Coles ME, Frost RO, Heimberg RG, Steketee G. (2003). Hoarding behaviors in a large college sample. Behaviour Research and Therapy, 41(2), 179-194.

Fernandez de la Cruz L, Landau D, Iervolino AC, Santo S, Pertusa A, Singh S, \& Mataix-Cols D. (2013). Experiential avoidance and emotion regulation difficulties in hoarding disorder. Joumal of Anxiety Disorders, 27(2), 204-209.

Frost RO, \& Hartl T. (1996). A cognitive-behavioral model of compulsive hoarding. Behavior Research and Therapy, 34 (4), 341-350.

Frost RO, Steketee G, \& Grisham J. (2004). Measurement of compulsive hoarding: Saving inventory revised. Behavior Research and Therapy, 42(10), 1163-1182.

Grisham JR, \& Barlow DH. (2005). Compulsive hoarding: Current research and theory. Journal of Psychopathology and Behavioral Assessment, 27(1), 45-52.

Khodaei A, \& Shokri O. (2010). Modeling the Structural Relationships among Personality Traits, Stress Coping Styles and Subjective Well-being of Male and Female Undergraduate Students, 4(16), 117-154. (Persian).

Levy HC, Worden BL, Gilliam CM, D’Urso C, Steketee G, Frost RO, \& Tolin DF. (2017). Changes in Saving Cognitions Mediate Hoarding Symptom Change in CognitiveBehavioral Therapy for Hoarding Disorder.

$$
\begin{aligned}
& \text { درمجموع يافتهاى اين بثزوهش نشان داد كه همسو با } \\
& \text { مدلهاى شناختى - رفتارى احتكار علاوه بر اجتناب } \\
& \text { تجربى رفتارهاى احتكارى با تلاش براى اجتناب از } \\
& \text { حمايتهاى درونى (شناختارهاى احتكارى) مرتبط } \\
& \text { است. اين يافتها از مدلهاى شناختى - رفتارى احتكار }
\end{aligned}
$$

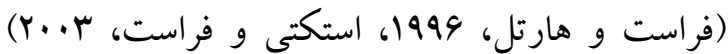

$$
\begin{aligned}
& \text { حمايت مى كند و بيشنهاد مىدهد كه شناختارهاى } \\
& \text { مربوط به متعلقات نقش مهمى را در رشد و حفظ } \\
& \text { مشكلات مربوط به احتكار اقلام غير لازم بازى مى كند. }
\end{aligned}
$$

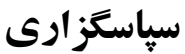

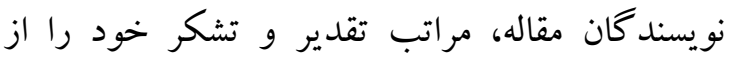

$$
\begin{aligned}
& \text { معاونت محترم يُزوهشى دانشگاه آزاد بيرجند و كليه } \\
& \text { دانشجويان شركت كننده در اين مطالعه، اعلام }
\end{aligned}
$$

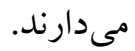

\section{References}

Abasi E, Fti L, Molodi H, \& Zarabi H. (2013). Psychometric properties of Persian Version of Acceptance and Action Questionnaire II. Joumal of Psychological Models and Methods, 3(10), 65-80. (Persian).

Allison C, Auyeung B, \& Baron-Cohen S. (2012). Toward Brief Red Flags for Autism Screening: The Short Autism Spectrum Quotient and the Short Quantitative Checklist in 1,000 Cases and 3,000 Controls. Joumal of the American Academy of Child and Adolescent Psychiatry, 51(2), 202-12.

American Psychiatric Association. (2013). DSM-5 Task Force. Diagnostic and statistical manual of mental disorders: DSM-5. 5th ed. Washington, DC; American Psychiatric Association.

Ayers CR, Castriotta N, Dozier ME, Espejo EP, \& Porter B. (2014). Behavioral and experiential avoidance in patients with hoarding disorder. Joumal of Behavior 
Journal of Obsessive-Compulsive and Related Disorders, 14, 112-188.

Mataix-Cols D, Frost RO, Pertusa A, Clark LA, Saxena S, \& Leckman JF. (2010).Hoarding disorder: A new diagnosis for DSM-V? Depression and Anxiety, 27(6), 556-572.

Misra R, Crist M, \& Burant CJ. (2003). Relationships among life stress, social support, academic stressors, and reactions to stressors of international students in the United States. International Joumal of Stress management, 10(2), 137-157.

Moghimi, Y. (2013). The Objects of Desire: A Cultural Case Study in Hoarding. Anthropol, 1,(109), 1-6.

Mohammadzadeh A. (2009).Validation of Saving Inventory-Revised (SI-R): Compulsive Hoarding Measure. Iranian Joumal of Psychiatry and Clinical Psychology,15(1),33-41. (Persian).

Olley A, Malhi G, \& Sachdev P. (2007). Memory and executive functioning in obsessivecompulsive disorder. A selective review. Journal of Affective Disorders, 104(1-3), 15-23.

Pertusa A, Bejerot S, Eriksson J, Femandez de la Cruz L, Bonde S, Russell A, \& Mataix-Cols D. (2012). Do patients with hoarding disorder have autistic traits? Depression and Anxiety, 29(3), 210-218.

Pertusa A, Frost RO, Fullana MA, Samuels JF, Steketee G, \& Tolin DF. (2010). Refining the diagnostic boundaries of compulsive hoarding: A critical review. Clinical Psychology Review, 30(4), 371-386.

Raines AM, Oglesby ME, Allan NP, Short NA, \& Schmidt NB. (2016) Understanding DSM5 Hoarding Disorder. A Triple Vulnerability Model. Psychiatry, 79(2), 120-129.

Reid JM, Amold E, Rosen S, Mason G, Larson MJ, Murphy TK, \& Storch EA. (2011). Hoarding behaviors among nonclinical elderly adults: Comelations with hoarding cognitions, obsessive-compulsive symptoms, and measures of general psychopathology. Joumal of Anxiety Disorders, 25(8), 1116-1122.

Ruta L, Mugno D, D'Arrigo VG, Vitiello B, Mazzone L. (2010). Obsessive-compulsive traits in children and adolescents with
Asperger syndrome. European Child Adolescent Psychiatry, 19(1), 17-24.

Samuels JF, Bienvenu OJ, Grados MA, Cullen B, Riddle MA, Liang KY, Eaton WW, \& Nestadt G. (2008). Prevalence and correlates of hoarding behavior in a community-based sample. Behaviour Research and Therapy, 46(7), 836-844.

Steketee G, \& Frost R. (2003). Compulsive hoarding: Cument status of the research. Clinical Psychology Review, 23(7), 905-927.

Steketee G, Frost R. (2014). Treatment for Hoarding Disorder: Workbook. New York: Oxford University Press.

Steketee G, Frost RO, Kyrios M. (2003). Cognitive aspects of compulsive hoarding. Cognitive Therapy and Research, 27(4), 463-479.

Taylor J. (2017). The role of emotion regulation in compulsive hoarding. School of Health Sciences, Department of Psychological Sciences Swinbume University of TechnologyHawthom, Victoria, Australia.

Timpano KR, Broman-Fulks JJ, Glaesmer H, Exner C, Rief W, Olatunji BO, \& Schmidt NB. (2013). A taxometric exploration of the latent structure of hoarding. Psychological Assessment, 25(1), 194-203.

Timpano KR, Buckner JD, Richey A, Murphy DL, \& Schmidt NB. (2009). Exploration of anxiety sensitivity and distress tolerance as vulnerability factors for hoarding behaviors. Depression and Anxiety, 26(4), 343-353.

Timpano KR, \& Schmidt NB. (2010).The association between hoarding and selfcontrol. Cognitive and Behavioral Practice, 17(4), 439-448.

Tolin DF, Frost, RO, \& Steketee G. (2010). A brief interview for assessing compulsive hoarding: The Hoarding Rating ScaleInterview. Psychiatry Research, 178(1), 147152.

Weston R, \& Gore PA. (2006). A Brief Guide to Structural Equation Modeling. The Counseling Psychologist, 34(5), 719-751.

Wheaton MG, Abramowitz JS, Franklin JC, Berman NC, \& Fabricant LE. (2011). Experiential avoidance and saving cognitions in the prediction of hoarding symptoms. Cognitive Therapy and Research, 35(6), 511-516. 
Wheaton MG, Fabricant LE, Berman NC, \& Abramowitz JS. (2013). Experiential avoidance in individuals with hoarding disorder. Cognitive Therapy and Research, 37(4), 779-785.

Williams AD. (2012). Distress tolerance and experiential avoidance in compulsive acquisition behaviors. Australian Journal of Psychology, 64(4), 217-224.

Xu W, Fu ZH, Wang J, \& Zhang YI. (2015). Relationship between autistic traits and hoarding in a large non-clinical Chinese sample: mediating effect of anxiety and depression. Psychological Reports: Disability \& Trauma, 116(1), 23-32. 